\title{
PENGARUH KUALITAS SISTEM TERHADAP KEPUASAN \\ PENGGUNA SISTEM KRS ON-LINE UNIVERSITAS AMIKOM YOGYAKARTA DENGAN KUALITAS INFORMASI DAN KEGUNAAN SEBAGAI MEDIATING VARIABEL
}

\author{
Ruhamah, Wing Wahyu Winarno, Asro Nasiri \\ Magister Teknik Informatika, STIE YKPN Yogyakarta, Universitas Amikom Yogyakarta \\ Universitas AMIKOM Yogyakarta \\ Jl. Ring Road Utara, Condong Catur, Depok, Sleman, Yogyakarta \\ Ruhamah.uma@gmail.com, Wingwahyuwinarno@gmail.com, Asro@amikom.ac.id
}

\begin{abstract}
KRS On-line Information System The University of AMIKOM Yogyakarta is an academic information system supporting student operational services especially those related to KRS, KHS and student value transcripts. This study aims to measure the level of student satisfaction as a user of On-line KRS information system by examining the quality factor of the system, the quality of information, perceived usefulness and student satisfaction, and using variable quality of information and perceived usefulness as the variable mediation or mediating variables.

This study was conducted by analyzing the questionnaire results from 100 respondents and the instruments used were questionnaires with Likert scale 5. Data analysis methods used Structural Equation Model (SEM) using Amos software. The result of analysis shows that system quality has no significant influence on user satisfaction with $p$ value = 0.659. while the quality of the system has a significant influence on the quality of information with a value of $p=0.00$. Information Quality has no significant effect on Perceived Use with $p$ value $=0.11$. Furthermore, the quality of the system has no significant effect on perceived usefulness with the value of $p=0.16$ but gives its effect through the quality of information with its total influence of 0.703. The quality of information has no significant effect on user satisfaction with $p=0.393$ but gives its effect through perceived usefulness with a total effect of 0.383 .
\end{abstract}

Keywords: information systems, On-line KRS, mediating variables.

Abstrak

Sistem Informasi KRS On-line Universitas AMIKOM Yogyakarta merupakan sistem informasi akademis penunjang operasional layanan kemahasiswaan khususnya yang berhubungan dengan KRS, KHS dan transkip nilai mahasiswa. Penelitian ini bertujuan untuk mengukur tingkat kepuasaan mahasiswa sebagai pengguna sistem informasi KRS On-line dengan mengkaji faktor kualitas sistem, kualitas informasi, kegunaan yang dirasakan dan kepuasan mahasiswa, serta menggunakan variabel kualitas informasi dan kegunaan yang dirasakan sebagai variabel mediasi atau mediating variabel.

Penelitian ini dilakukan dengan menganalisis hasil kuesioner dari 100 responden dan instrumen yang digunakan adalah kuesioner dengan skala likert 5. Metode analisis data yang digunakan Structural Equation Model (SEM) dengan menggunakan software Amos 21. Hasil analisis menunjukkan bahwa kualitas sistem tidak memiliki pengaruh signifikan terhadap kepuasaan pengguna dengan nilai $\mathrm{p}=0.659$. sementara kualitas sistem memiliki pengaruh signifikan terhadap kualitas informasi dengan nilai $\mathrm{p}=0.00$. Kualitas Informasi tidak memiliki pengaruh yang signifikan terhadap Kegunaan yang Dirasakan dengan nilai $\mathrm{p}=0.11$. Selanjutnya, kualitas sistem tidak memiliki pengaruh yang signifikan terhadap kegunaan 
yang dirasakan dengan nilai $\mathrm{p}=0.16$ tetapi memberikan pengaruhnya melalui kualitas informasi dengan pengaruh totalnya sebesar 0.703. Kualitas informasi tidak memiliki pengaruh yang signifikan terhadap kepuasaan pengguna dengan $\mathrm{p}=0.393$ tetapi memberikan pengaruhnya melalui kegunaan yang dirasakan dengan pengaruh totalnya sebesar 0.383 .

Kata kunci: sistem informasi, KRS On-line, mediating variabel

\section{Pendahuluan}

Organisasi pendidikan perlu memanfaatkan perkembangan Sistem Informasi dan Teknologi Informasi secara optimal dengan membuat dan menyediakan Sistem Informasi untuk mendukung pengoperasian sistem tata-kelola pendidikan, misalnya dengan merancang dan mengimplementasikan Sistem Informasi Akademis sehingga sistem informasi ini dapat meningkatkan citra organisasi dan sekaligus memberikan kemudahan bagi komunitas kampus dalam proses dan kegiatan pendidikan. Salah satu bagian dari Sistem Informasi Akademis yang telah dikembangkan dan diselenggarakan oleh organisasi pendidikan adalah proses administrasi Kartu Rencana Studi berbasis on-line (KRS On-line).

Kesuksesan sistem informasi merupakan suatu tingkat dimana sistem informasi mampu memberikan kontribusi pada organisasi dalam pencapaian tujuannya. Sebaliknya dikatakan gagal apabila sistem tersebut kurang atau bahkan tidak dimanfaatkan oleh penggunanya. Agar suatu sistem informasi dapat beroperasi secara optimal, perlu adanya evaluasi terhadap sistem informasi. Karena biaya yang dikeluarkan untuk menerapkan sistem informasi yang berbasis teknologi informasi tidak sedikit maka kepuasan pengguna merupakan salah satu bentuk evaluasi terhadap sistem informasi. Salah satu metode yang dikembangkan oleh ahli sistem informasi untuk mengukur kepuasan pengguna sistem informasi adalah dengan menilai karakteristik yang diinginkan dari sebuah sistem (kualitas sistem), karakteristik yang diinginkan dari output sistem (kualitas informasi) dan kualitas dukungan yang diterima pengguna sistem dari departemen sistem informasi dan dukungan personil informasi.

Universitas AMIKOM Yogyakarta sejak tahun 2003 telah merancang dan tahun 2004 telah membangun KRS On-Line sebagai bagian dari Sistem Informasi Akademis. Penelitian ini bermaksud menggunakan Sistem KRS On-line Universitas AMIKOM Yogyakarta sebagai objek penelitian dengan mengkaji variabel kualitas sistem, kualitas informasi, kegunaan yang dirasakan untuk mengukur tingkat kepuasaan pengguna (mahasiswa) terhadap Sistem KRS On-line.

\section{Metode Penelitian}

Metode penelitian yang digunakan pada penelitian ini adalah metode penelitian kuantitatif dengan menggunakan metode pendekatan survei. Penelitian dengan pendekatan survei mengambil sampel dari satu populasi dan menggunakan kuesioner yang dibangun sendiri sebagai alat pengumpulan data yang pokok. Penelitian survei yang dilakukan bersifat penjelasan (explanatory), yaitu menjelaskan hubungan kausal antara variabel-variabel yang mempengaruhi Kepuasaan Pengguna sistem informasi KRS Online Universitas AMIKOM Yogyakarta dengan menggunakan model kesuksesan sistem informasi Delone \& Mclean dan TAM. Penelitian ini menggunakan metode pengumpulan data yaitu metode wawancara, metode observasi dan kuesioner. Responden akan memberikan jawaban kualitatif yang akan diukur dengan skala likert untuk setiap pertanyaan kuesioner. Skala yang digunakan adalah skala likert lima dengan ketentuan, Sangat Tidak Setuju (STS), Tidak Setuju (TS), Netral (N), Setuju (S) dan Sangat Setuju (SS). Lima klasifikasi jawaban akan diukur dengan nilai $1-5$. Pada penelitian ini, data yang terkumpul akan diolah dengan menggunakan kerangka analisis 
Model Persamaan Struktural (SEM) dengan alat bantu olahdata AMOS 21. Untuk memberikan pemahaman tentang variabel-variabel yang digunakan dalam penelitian ini, berikut defenisi variabel beserta indikator yang digunakan dalam penelitian yang ditunjukkan pada Tabel 1 berikut.

Tabel 1 Defenisi dan Indikator Variabel Penelitian

\begin{tabular}{|l|l|l|}
\hline \multicolumn{1}{|c|}{$\begin{array}{c}\text { Nama } \\
\text { variabel }\end{array}$} & \multicolumn{1}{|c|}{ Penjelasan } & \multicolumn{1}{c|}{ Indikator variabel } \\
\hline $\begin{array}{l}\text { Kualitas } \\
\text { Sistem }\end{array}$ & $\begin{array}{l}\text { Performa yang merujuk pada } \\
\text { seberapa baik kemampuan perangkat } \\
\text { keras, perangkat lunak, prosedur dan } \\
\text { kebijakan dari sistem informasi dapat } \\
\text { menyediakan informasi kebutuhan } \\
\text { pengguna }\end{array}$ & $\begin{array}{l}\text { leliability, accesbility dan respons } \\
\text { (Wixom, dkk., 2005) dan } \\
\text { (Montesdioca, dkk., 2015) }\end{array}$ \\
\hline $\begin{array}{l}\text { Kualitas } \\
\text { Informasi }\end{array}$ & $\begin{array}{l}\text { Merupakan semua bentuk keluaran } \\
\text { informasi atau laporan yang } \\
\text { dihasilkan dari Sistem Pelayanan } \\
\text { KRS On-line (Wixom, dkk., 2005) }\end{array}$ & $\begin{array}{l}\text { kelengkapan informasi (completeness), } \\
\text { ketelitian (accuracy), } \\
\text { format/presentation dan kekinian } \\
\text { (currency). (Wixom, dkk., 2005) dan } \\
\text { (Montesdioca, dkk., 2015) }\end{array}$ \\
\hline $\begin{array}{l}\text { Kegunaann } \\
\text { yang } \\
\text { dirasakan }\end{array}$ & $\begin{array}{l}\text { Suatu tindakan yang seseorang } \\
\text { percaya bahwa dengan menggunakan } \\
\text { sistem tersebut dapat meningkatkan } \\
\text { kinerjanya dalam bekerja }\end{array}$ & $\begin{array}{l}\text { work more quickly (mengerjakan tugas } \\
\text { lebih cepat), increased } \\
\text { productivity/effectiveness, make job } \\
\text { easier (mengerjakan tugas lebih } \\
\text { mudah), dan } \text { useful (bermanfaat) } \\
\text { (Davis, 1989) }\end{array}$ \\
\hline $\begin{array}{l}\text { Kepuasaan } \\
\text { Pengguna }\end{array}$ & $\begin{array}{l}\text { Tingkat sejauh mana sistem informasi } \\
\text { dapat membantu pengguna untuk } \\
\text { menciptakan nilai bagi pengguna }\end{array}$ & $\begin{array}{l}\text { Adequate, overall satisfaction dan the } \\
\text { system has met user expectation } \\
\text { (Palvia, 1996 dan Kassim dkk., 2012). }\end{array}$ \\
\hline
\end{tabular}

Kualitas sistem merupakan ciri karakteristik kualitas yang diinginkan dari sistem informasi itu sendiri dan kualitas informasi yang diinginkan dari informasi karakteristik produk (DeLone \& McLean, 1992). Hasil penelitian Yuliana (2016), menunjukkan bahwa kualitas sistem berpengaruh signifikan terhadap kepuasan pengguna. Selanjutnya, Kualitas Sistem dan Kualitas Informasi tidak mempengaruhi terhadap Penggunaan. Begitu juga kualitas Informasi tidak mempengaruhi terhadap Kepuasaan Pengguna. Hasil penelitian Riyanto (2018), persamaan regresi ke-1 menunjukkan bahwa kualitas sistem pengaruhnya tidak signifikan terhadap kegunaan yang dirasakan, sedangkan kualitas informasi dan kemudahan yang dirasakan memiliki pengaruh yang signifikan.

Variabel kualitas sistem kemungkinan besar tidak memberikan pengaruh secara langsung, namun memberikan pengaruhnya melalui kualitas informasi sebagai mediating variabel. Selanjutnya, persamaan regresi ke-2, menunjukkan bahwa kualitas sistem dan kegunaan yang dirasakan memiliki pengaruh signifikan terhadap kepuasaan pengguna, sedangkan kualitas informasi dan kemudahan yang dirasakan pengaruhnya tidak signifikan terhadap kepuasaan pengguna. Hal ini menunjukkan peran variabel Kegunaan yang dirasakan sebagai mediating variabel memiliki pengaruh terhadap kepuasaan pengguna. Berdasakan hal tersebut diatas maka dapat digambarkan kerangka penelitian seperti yang disajikan pada Gambar . 


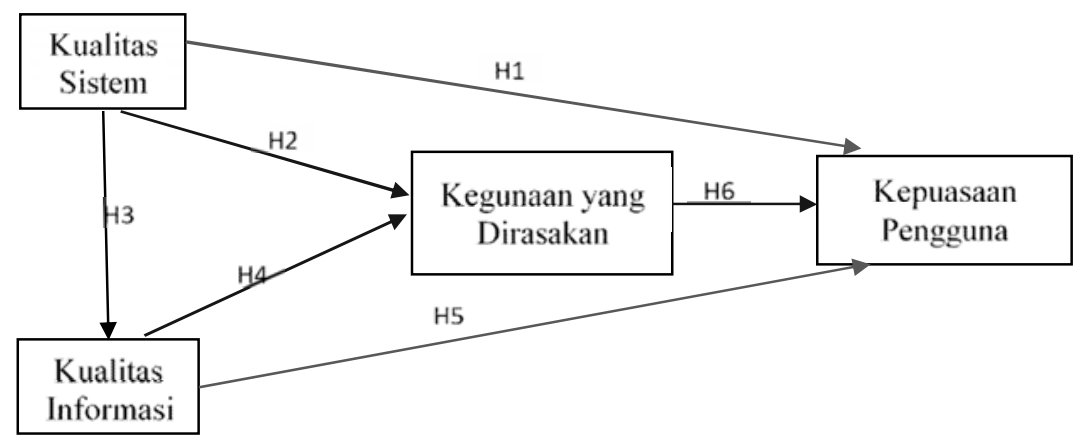

Gambar 1. Kerangka Penelitian

Tabel 2 Kategorisasi Variabel Penelitian

\begin{tabular}{|c|c|c|c|c|c|}
\hline \multicolumn{6}{|c|}{ Variabel Kualitas Sistem } \\
\hline & & Frequency & Percent & Valid Percent & Cumulative Percent \\
\hline \multirow{6}{*}{ Valid } & Sangat Tidak Setuju & 5 & 5.0 & 5.0 & 5.0 \\
\hline & Tidak Setuju & 10 & 10.0 & 10.0 & 15.0 \\
\hline & Netral & 46 & 46.0 & 46.0 & 61.0 \\
\hline & Setuju & 35 & 35.0 & 35.0 & 96.0 \\
\hline & Sangat Setuju & 4 & 4.0 & 4.0 & 100.0 \\
\hline & Total & 100 & 100.0 & 100.0 & \\
\hline \multicolumn{6}{|c|}{ Variabel Kualitas Informasi } \\
\hline & & Frequency & Percent & Valid Percent & Cumulative Percent \\
\hline \multirow{6}{*}{ Valid } & Sangat Tidak Setuju & 1 & 1.0 & 1.0 & 1.0 \\
\hline & Tidak Setuju & 18 & 18.0 & 18.0 & 19.0 \\
\hline & Netral & 50 & 50.0 & 50.0 & 69.0 \\
\hline & Setuju & 23 & 23.0 & 23.0 & 92.0 \\
\hline & Sangat Setuju & 8 & 8.0 & 8.0 & 100.0 \\
\hline & Total & 100 & 100.0 & 100.0 & \\
\hline \multicolumn{6}{|c|}{ Variabel Kegunaan yang Dirasakan } \\
\hline & & Frequency & Percent & Valid Percent & Cumulative Percent \\
\hline \multirow{5}{*}{ Valid } & Tidak Setuju & 2 & 2.0 & 2.0 & 2.0 \\
\hline & Netral & 20 & 20.0 & 20.0 & 22.0 \\
\hline & Setuju & 50 & 50.0 & 50.0 & 72.0 \\
\hline & Sangat Setuju & 28 & 28.0 & 28.0 & 100.0 \\
\hline & Total & 100 & 100.0 & 100.0 & \\
\hline \multicolumn{6}{|c|}{ Variabel Kepuasaan Pengguna } \\
\hline & & Frequency & Percent & Valid Percent & Cumulative Percent \\
\hline \multirow{6}{*}{ Valid } & Sangat Tidak Setuju & 2 & 2.0 & 2.0 & 2.0 \\
\hline & Tidak Setuju & 4 & 4.0 & 4.0 & 6.0 \\
\hline & Netral & 41 & 41.0 & 41.0 & 47.0 \\
\hline & Setuju & 45 & 45.0 & 45.0 & 92.0 \\
\hline & Sangat Setuju & 8 & 8.0 & 8.0 & 100.0 \\
\hline & Total & 100 & 100.0 & 100.0 & \\
\hline
\end{tabular}


Berdasarkan kerangka penelitian di atas maka dapat dirumuskan enam hipotesis berikut ini:

H1 : Kualitas Sistem KRS On-line Universitas AMIKOM Yogyakarta memiliki pengaruh signifikan terhadap Kepuasaan Pengguna

H2 : Kegunaan yang dirasakan pada Sistem KRS On-line Universitas AMIKOM Yogyakarta memediasi pengaruh Kualitas Informasi terhadap Kepuasaan Pengguna

H3 : Kualitas Sistem KRS On-line Universitas AMIKOM Yogyakarta memiliki pengaruh signifikan terhadap Kualitas Informasi

H4 : Kualitas Informasi pada Sistem KRS On-line Universitas AMIKOM Yogyakarta memiliki pengaruh yang signifikan terhadap Kegunaan yang Dirasakan

H5 : Kualitas Informasi pada Sistem KRS On-line Universitas AMIKOM Yogyakarta memediasi pengaruh Kualitas Sistem terhadap Kegunaan yang dirasakan.

H6 : Kegunaan yang dirasakan pada Sistem KRS On-line Universitas AMIKOM Yogyakarta memiliki pengaruh signifikan terhadap Kepuasaan Pengguna.

Populasi dalam penelitian ini adalah mahasiswa Universitas AMIKOM Yogyakarta selaku pengguna sistem KRS On-line dengan sampel sebanyak 100 orang. Adapun deskripsi data yang disajikan adalah kategorisasi variabel yang digunakan dalam penelitian ini yang meliputi, kategorisasi variabel kualitas sistem, kategorisasi variabel kualitas informasi, kategorisasi variabel kegunaan yang dirasakan dan kategorisasi variabel kepuasaan pengguna mengenai perolehan data hasil penyebaran kuesioner kepada 100 responden. Berikut jawaban responden untuk masing-masing variabel.

\section{Hasil dan Pembahasan}

\section{Hasil Uji Validitas}

Dalam penelitian ini, ada empat instrumen yang akan divalidasi sebelum digunakan untuk mengumpulkan data dilapangan yaitu Kualitas Sistem, Kualitas Informasi, Kegunaan yang Dirasakan dan Kepuasan Pengguna. Setelah melakukan penyusunan instrumen dan menyesuaikan instrumen dengan kisi-kisi yang dibuat, kemudian dilanjutkan dengan uji coba instrumen kepada 30 mahasiswa. Berdasarkan hasil perhitungan, apabila nilai correct itemtotal correction tersebut $\geq 30$ maka butir pertanyaan dalam angket dinyatakan valid atau sahih (Azwar, 2006). Hasil ujicoba dengan metode correct item-total correction ditunjukkan pada Tabel 3 berikut ini:

Tabel 3 Hasil Uji Validitas Butir Instumen

\begin{tabular}{|c|c|c|c|c|}
\hline \multicolumn{5}{|c|}{ Variabel Kualitas Sistem } \\
\hline No & Butir Pertanyaan & $\begin{array}{c}\text { Correct item - total } \\
\text { correction }\end{array}$ & Syarat Minimal & Keterangan \\
\hline 1 & KS1 & 0.555 & 0.30 & Valid \\
\hline 2 & KS2 & 0.668 & 0.30 & Valid \\
\hline 3 & KS3 & 0.710 & 0.30 & Valid \\
\hline 4 & KS4 & 0.585 & 0.30 & Valid \\
\hline 5 & KS5 & 0.733 & 0.30 & Valid \\
\hline \multicolumn{5}{|c|}{ Variabel Kualitas Informasi } \\
\hline No & Butir Pertanyaan & $\begin{array}{c}\text { Correct item - total } \\
\text { correction }\end{array}$ & Syarat Minimal & Keterangan \\
\hline 1 & KI1 & 0.836 & 0.30 & Valid \\
\hline 2 & KI2 & 0.840 & 0.30 & Valid \\
\hline 3 & KI3 & 0.800 & 0.30 & Valid \\
\hline
\end{tabular}




\begin{tabular}{|c|c|c|c|c|}
\hline 4 & KI4 & 0.737 & 0.30 & Valid \\
\hline \multicolumn{5}{|c|}{ Variabel Kegunaan yang Dirasakan } \\
\hline No & Butir Pertanyaan & $\begin{array}{c}\text { Correct item - total } \\
\text { correction }\end{array}$ & Syarat Minimal & Keterangan \\
\hline 1 & KGR1 & 0.815 & 0.30 & Valid \\
\hline 2 & KGR2 & 0.908 & 0.30 & Valid \\
\hline 3 & KGR3 & 0.510 & 0.30 & Valid \\
\hline 4 & KGR4 & 0.662 & 0.30 & Valid \\
\hline 5 & KGR5 & 0.746 & 0.30 & Valid \\
\hline \multicolumn{5}{|c|}{ Variabel Kepuasaan Pengguna } \\
\hline No & Butir Pertanyaan & $\begin{array}{c}\text { Correct item - total } \\
\text { correction }\end{array}$ & Syarat Minimal & Keterangan \\
\hline 1 & KP1 & 0.714 & 0.30 & Valid \\
\hline 2 & KP2 & 0.880 & 0.30 & Valid \\
\hline 3 & KP3 & 0.899 & 0.30 & Valid \\
\hline
\end{tabular}

2. Hasil Uji Reliabilitas

Pengujian reliabilitas yang digunakan adalah metode Cronbach Alpha. Suatu instrumen dikatakan reliabel (andal) bila memiliki koefesien Alpha Cronbach $\geq 70$ (Hair, dkk, 2010). Hasil uji reliabilitas (Cronbach's alpha) ditunjukkan pada Tabel 4 berikut.

Tabel 4 Hasil Uji Reliabilitas Butir Instrumen

\begin{tabular}{|l|c|c|c|}
\hline \multicolumn{1}{|c|}{ Variabel } & Alpha Cronbach & Syarat minimal & Keterangan \\
\hline Kualitas Sistem & 0.842 & 0.70 & Reliabel \\
\hline Kualitas Informasi & 0.913 & 0.70 & Reliabel \\
\hline Kegunaan yang Dirasakan & 0.884 & 0.70 & Reliabel \\
\hline Kepuasaan Pengguna & 0.913 & 0.70 & Reliabel \\
\hline
\end{tabular}

3. Hasil Uji Normalitas

Uji normalitas dilakukan untuk melihat tingkat kenormalan data yang digunakan, apakah data berdistribusi normal atau tidak. Normal tidaknya distribusi data dapat dilihat dari nilai critical ratio (CR) pada skewness dan kurtosis. Angka pembanding CR adalah angka Z. Pada umumnya digunakan tingkat kepercayaan $99 \%$, pada tingkat kepercayaan tersebut tingkat signifikansi adalah 0,01 atau $1 \%$ didapat angka $\mathrm{Z}$ adalah 2,58. Dengan demikian sebuah distribusi data dikatakan normal jika angka cr skewness atau angka cr kurtosis ada diantara 2,58 sampai 2,58. Namun jika angka-angka tersebut ada di bawah -2,58 (misal -4, -5 dsb) atau di atas 2,58, distribusi data dapat dikatakan tidak normal. (Santoso, 2015). Hasil uji normalitas dapat dilihat pada Tabel 5 berikut ini.

Tabel 5 Hasil Uji Normalitas

\begin{tabular}{|c|rrrrrr|}
\hline Variable & $\min$ & $\max$ & skew & c.r. & kurtosis & c.r. \\
\hline KGR1 & 2.000 & 5.000 & -.194 & -.791 & -1.041 & -2.125 \\
KGR2 & 2.000 & 5.000 & -.456 & -1.863 & -.286 & -.583 \\
KGR3 & 2.000 & 5.000 & -.011 & -.045 & -.819 & -1.672 \\
KGR4 & 2.000 & 5.000 & -.203 & -.828 & -.785 & -1.603 \\
KGR5 & 2.000 & 5.000 & -.391 & -1.597 & -.995 & -2.030 \\
KP3 & 1.000 & 5.000 & -.355 & -1.448 & .103 & .210 \\
KP2 & 1.000 & 5.000 & -.515 & -2.101 & .883 & 1.803 \\
KP1 & 1.000 & 5.000 & -.279 & -1.139 & .836 & 1.707 \\
KI1 & 1.000 & 5.000 & -.261 & -1.064 & -.504 & -1.028 \\
KI2 & 1.000 & 5.000 & .527 & 2.150 & -.221 & -.451 \\
\hline
\end{tabular}




\begin{tabular}{|c|rrrrrr|}
\hline Variable & $\min$ & $\max$ & skew & c.r. & kurtosis & c.r. \\
\hline KI3 & 1.000 & 5.000 & .422 & 1.722 & -.434 & -.887 \\
KI4 & 1.000 & 5.000 & .138 & .563 & -.653 & -1.333 \\
KS1 & 1.000 & 5.000 & -.451 & -1.841 & -.549 & -1.121 \\
KS2 & 1.000 & 5.000 & .105 & .429 & -1.074 & -2.191 \\
KS3 & 1.000 & 5.000 & .405 & 1.652 & -.287 & -.585 \\
KS4 & 1.000 & 5.000 & -.421 & -1.720 & -.007 & -.015 \\
KS5 & 1.000 & 5.000 & -.055 & -.226 & -.095 & -.193 \\
Multivariate & & & & & 9.919 & 1.951 \\
\hline
\end{tabular}

4. Hasil Uji Goodness of FIT

Hasil uji Goodness of Fit setelah modifikasi model dirangkum berdasarkan ukuran kecocokan absolut dan inkremental (Sitinjak, dkk, 2006), dapat dilihat pada Tabel 6 berikut ini.

Tabel 6 Hasil Uji Goodness of Fit setelah Modifikasi Model

\begin{tabular}{|l|c|c|c|c|}
\hline \multicolumn{1}{|c|}{ Goodness of Fit } & Cut off value & Hasil & Keputusan & Keterangan \\
\hline Probabilitas Chi-square & $\geq 0.05$ & 0.60 & Good Fit & \\
\hline CMIN/DF & $<2$ & 1.215 & Good Fit & \\
\hline GFI & $\geq 0.90$ & 0.865 & Marginal Fit & GFI $\geq 0.80$ \\
\hline AGFI & $\geq 0.90$ & 0.819 & Marginal Fit & AGFI $\geq 0.80$ \\
\hline NFI & $\geq 0.90$ & 0.851 & Marginal Fit & NFI $\geq 0.80$ \\
\hline RFI & $\geq 0.90$ & 0.821 & Marginal Fit & RFI $\geq 0.80$ \\
\hline IFI & $\geq 0.90$ & 0.938 & Good Fit & \\
\hline TLI & $\geq 0.90$ & 0.924 & Good Fit & \\
\hline CFI & $\geq 0.90$ & 0.937 & Good Fit & \\
\hline RMSEA & $\leq 0.08$ & 0.064 & Good Fit & \\
\hline
\end{tabular}

5. Hasil Uji Measurement Model dan Structural Model

Hasil uji kesesuain model meliputi Measurement model dan structural model. Measurement model adalah bagian dari SEM yang menggambarkan hubungan antara variabel laten dengan indikator-indikatornya, sedangkan structural model menggambarkan hubungan antar variabel-variabel laten atau variabel konstruk. Hasil uji structural model dirangkum dalam Tabel 7 berikut ini.

Tabel 7 Hasil Uji Structural Model

\begin{tabular}{|lll|ccccc|}
\hline & & & Estimate & S.E. & C.R & P & Label \\
\hline Kualitas_Informasi & $<---$ & Kualitas_Sistem & .825 & .172 & 4.78 & $* * *$ & par_19 \\
Kegunaan_Dirasakn & $<---$ & Kualitas_Informsi & .374 & .147 & 2.53 & .011 & par_14 \\
Kegunaan_Dirasakn & $<---$ & Kualitas_Sistem & .411 & .171 & 2.40 & .016 & par_15 \\
Kepuasan_Pngguna & $<---$ & Kgunaan_Dirsakn & .595 & .145 & 4.11 & $* * *$ & par_16 \\
Kepuasan_Pngguna & $<---$ & Kualitas_Informsi & .114 & .134 & .854 & .393 & par_17 \\
Kepuasan_Pngguna & $<---$ & Kualitas_Sistem & .069 & .157 & .441 & .659 & par_18 \\
KS5 & $<---$ & Kualitas_Sistem & 1.000 & & & & \\
KS4 & $<---$ & Kualitas_Sistem & .999 & .170 & 5.87 & $* * *$ & par_1 \\
KS3 & $<---$ & Kualitas_Sistem & 1.157 & .187 & 6.17 & $* * *$ & par_2 \\
\hline
\end{tabular}

Selanjutnya hasil uji Measuremenl model dapat dilihat pada Tabel 8 berikut:

Tabel 8 Hasil uji Measurement Model

\begin{tabular}{|l|rcccc|}
\hline & Estimate & S.E. & C.R. & P & Label \\
\hline Kualitas_Sistem & .420 & .118 & 3.544 & $* * *$ & par_20 \\
\hline
\end{tabular}




\begin{tabular}{|l|rrrcc|}
\hline & Estimate & S.E. & C.R. & P & Label \\
\hline Z1 & .236 & .074 & 3.187 & .001 & par_21 \\
Z2 & .190 & .048 & 3.999 & $* * *$ & par_22 \\
Z3 1 & .163 & .040 & 4.064 & $* * *$ & par_23 \\
e2 & .494 & .084 & 5.894 & $* * *$ & par_24 \\
e3 & .503 & .084 & 5.961 & $* * *$ & par_25 \\
e4 & .506 & .090 & 5.629 & $* * *$ & par_26 \\
e5 & .926 & .153 & 6.037 & $* * *$ & par_27 \\
e6 & .645 & .113 & 5.695 & $* * *$ & par_28 \\
e7 & .618 & .098 & 6.288 & $* * *$ & par_29 \\
e8 & .236 & .049 & 4.772 & $* * *$ & par_30 \\
e9 & .195 & .046 & 4.194 & $* * *$ & par_31 \\
e10 & .641 & .102 & 6.278 & $* * *$ & par_32 \\
e11 & .205 & .036 & 5.656 & $* * *$ & par_33 \\
e12 & .097 & .035 & 2.750 & .006 & par_34 \\
e13 & .327 & .056 & 5.842 & $* * *$ & par_35 \\
e14 & .269 & .047 & 5.776 & $* * *$ & par_36 \\
e15 & .242 & .042 & 5.712 & $* * *$ & par_37 \\
e16 & .235 & .040 & 5.838 & $* * *$ & par_38 \\
e17 & .280 & .043 & 6.466 & $* * *$ & par_39 \\
\hline
\end{tabular}

6. Hasil Uji Hipotesis

Setelah secara keseluruhan sebuah structural model dapat dianggap fit, proses selanjutnya adalah melihat apakah ada pengaruh yang signifikan antara variabel independen dengan variabel dependen dengan melihat hasil uji structural model dan adakah pengaruh antara variabel independen dengan variabel dependen melalui variabel mediator dengan melihat pengaruh langsung dan pengaruh tidak langsung serta seberapa besar pengaruh (total effect) variabel mediator tersebut.

Tabel 9 Hasil Uji Structural Model

\begin{tabular}{|lcl|ccccc|}
\hline & & & Estimate & S.E. & C.R & P & Label \\
\hline Kualitas_Informasi & $<---$ & Kualitas_Sistem & .825 & .172 & 4.78 & $* * *$ & par_19 \\
Kegunaan_Dirasakn & $<---$ & Kualitas_Informsi & .374 & .147 & 2.53 & .011 & par_14 \\
Kegunaan_Dirasakn & $<---$ & Kualitas_Sistem & .411 & .171 & 2.40 & .016 & par_15 \\
Kepuasan_Pngguna & $<---$ & Kgunaan_Dirsakn & .595 & .145 & 4.11 & $* * *$ & par_16 \\
Kepuasan_Pngguna & $<---$ & Kualitas_Informsi & .114 & .134 & .854 & .393 & par_17 \\
Kepuasan_Pngguna & $<---$ & Kualitas_Sistem & .069 & .157 & .441 & .659 & par_18 \\
\hline
\end{tabular}

Tabel 10 Pengaruh Langsung (Direct Effect)

\begin{tabular}{|l|rrrr|}
\hline & $\begin{array}{r}\text { Kualitas_S } \\
\text { istem }\end{array}$ & $\begin{array}{r}\text { Kualitas_Inform } \\
\text { asi }\end{array}$ & $\begin{array}{r}\text { Kegunaan_Dirasak } \\
\text { an }\end{array}$ & $\begin{array}{r}\text { Kepuasan_Penggu } \\
\text { na }\end{array}$ \\
\hline Kualitas_Informasi & .740 & .000 & .000 & .000 \\
Kegunaan_Dirasakan & .401 & .407 & .000 & .000 \\
Kepuasan_Pengguna & .071 & .130 & .621 & .000 \\
\hline
\end{tabular}

Tabel 11 Pengaruh Tidak Langsung (Indirect Effect)

\begin{tabular}{|r|rrrr|}
\hline & Kualitas_Sis & Kualitas_Inform & Kegunaan_Dirasak & Kepuasan_Penggu \\
tem & asi & na & an \\
\hline
\end{tabular}


Pengaruh Kualitas Sistem Terhadap Kepuasan Pengguna Sistem Krs On-Line Universitas Amikom Yogyakarta dengan...

\begin{tabular}{|c|c|c|c|c|}
\hline & $\begin{array}{r}\text { Kualitas_Sis } \\
\text { tem }\end{array}$ & $\begin{array}{r}\text { Kualitas_Inform } \\
\text { asi }\end{array}$ & $\begin{array}{r}\text { Kegunaan_Dirasak } \\
\text { an }\end{array}$ & $\begin{array}{r}\text { Kepuasan_Penggu } \\
\text { na }\end{array}$ \\
\hline Kualitas_Informasi & .000 & .000 & .000 & .000 \\
\hline Kegunaan_Dirasakan & .301 & .000 & .000 & .000 \\
\hline Kepuasan_Pengguna & .533 & .253 & .000 & .000 \\
\hline
\end{tabular}

Tabel 12 Pengaruh Total (Total Effect)

\begin{tabular}{|l|rrrr|}
\hline & $\begin{array}{r}\text { Kualitas } \\
\text { Sistem }\end{array}$ & $\begin{array}{r}\text { Kualitas_Infor } \\
\text { masi }\end{array}$ & $\begin{array}{r}\text { Kegunaan_Diras } \\
\text { akan }\end{array}$ & $\begin{array}{r}\text { Kepuasan_Peng } \\
\text { guna }\end{array}$ \\
\hline Kualitas_Informasi & .740 & .000 & .000 & .000 \\
Kegunaan_Dirasakan & .703 & .407 & .000 & .000 \\
Kepuasan_Pengguna & .603 & .383 & .621 & .000 \\
\hline
\end{tabular}

Kriteria pengujian hipotesis yang digunakan adalah jika nilai probabilitas $(\mathrm{P})>0,05$ maka hipotesis ditolak sedangkan jika nilai $\mathrm{P}$ (probabilitas) $<0,05$ maka hipotesis diterima. Berdasarkan Tabel 9, Tabel 10, Tabel 11 dan Tabel 12 di atas, dapat ditarik kesimpulan hasil uji hipotesis pada penelitian ini sebagai barikut:

H1 : Kualitas Sistem KRS On-line Universitas Amikom Yogyakarta memiliki pengaruh signifikan terhadap Kepuasaan Pengguna ditolak karena nilai $p=0.659$ lebih besar dari 0.05 $(0.659>0.05)$. ini menunjukkan bahwa semakin berkualitas sistem KRS On-line, belum tentu memberikan kepuasaan bagi penggunanya. Hal ini dikarenakan pengguna dalam mengimplementasikan KRS On-line tidak berdasarkan kualitas sistem, namun lebih karena mahasiswa wajib menggunakan sistem ini dan tidak ada alternatif lain.

H2 : Kegunaan yang dirasakan pada Sistem KRS On-line Universitas Amikom Yogyakarta memediasi pengaruh Kualitas Informasi terhadap Kepuasaan Pengguna ditolak karena nilai $p$ $=0.393$ lebih besar dari $0.05(0.393>0.05)$. Pengujian hopitesis ini menunjukkan tidak adanya pengaruh yang signifikan dari kualitas informasi terhadap kepuasaan pengguna melalui kegunaan yang dirasakan. Hal ini berarti bahwa kualitas informasi yang disajikan pada sistem ini tidak memberikan kepuasaan bagi penggunanya. Dari hasil kuesioner, responden merasa bahwa terdapat beberapa informasi yang penting bagi pengguna namun tidak ditampilkan pada sistem KRS On-line ini. Misalnya, tidak ada pemberitahuan bahwa proses pengisian KRS telah sukses, pemilihan matakuliah pilihan dengan jumlah kelas yang terbatas, dan belum terintegrasinya nilai dari kampus sebelumnya. Perlu dilakukan pembenahan kualitas sistem untuk menghasilkan kualitas informasi yang baik bagi penggunanya. Dari hasil analisis menunjukkan bahwa kualitas informasi tidak memberikan pengaruh yang signifikan terhadap kepuasaan pengguna tetapi memberikan pengaruhnya melalui kegunaan yang dirasakan. Hal ini menunjukkan bahwa informasi yang disajikan dari sistem ini memberikan kecepatan dan kemudahan pengguna dalam menyelesaikan pekerjaan atau tugasnya. Dengan demikian pengguna akan merasakan manfaat dari sistem ini yang pada gilirannya akan memberikan kepuasaan bagi pengguna.

H3 : Kualitas Sistem KRS On-line Universitas Amikom Yogyakarta memiliki pengaruh signifikan terhadap Kualitas Informasi diterima karena nilai $p=0.00(<0.05)$. Hal ini berarti bahwa kualitas sistem menjadi faktor yang sangat penting dalam memberikan atau menyajikan informasi bagi pengguna. Semakin baik kualitas sebuah sistem maka semakin baik pula informasi yang disajikan.

H4 : Kualitas Informasi pada Sistem KRS On-line Universitas Amikom Yogyakarta memiliki pengaruh yang signifikan terhadap Kegunaan yang Dirasakan ditolak karena nilai $p=0.11$ lebih besar dari $0.05(0.11>0.05)$. Artinya bahwa, informasi yang disajikan sistem KRS Online ini tidak memberikan kemudahan bagi pengguna dalam mengerjakan tugas lebih cepat dan lebih mudah. 
H5 : Kualitas Informasi pada Sistem KRS On-line Universitas Amikom Yogyakarta memediasi pengaruh Kualitas Sistem terhadap Kegunaan ditolak karena nilai $p=0.16$ lebih besar dari $0.05(0.16>0.05)$. tidak diterimanya hipotesis 5 (H5) menunjukkan bahwa semakin berkualitasnya sistem KRS On-line, belum tentu meningkatkan kegunaan yang dirasakan pengguna. Walaupun ada pengguna yang menganggap kualitas sistem belum maksimal namun hal ini tidak mempengaruhi bagi penggunaan sistem, karena pengguna menganggap sistem KRS On-line ini bermanfaat dan juga merupakan suatu kebutuhan bagi pengguna, karena tidak ada sistem lain yang memiliki fasilitas sama dengan sistem KRS Online, sehingga pengguna harus dan hanya bisa menggunakan sistem ini untuk mendukung pekerjaannya. Hasil analisis menunjukkan bahwa kualitas sistem tidak memiliki pengaruh yang signifikan terhadap kegunaan yang dirasakan melalui kualitas informasi, hal ini berarti bahwa semakin baik sebuah sistem menyajikan informasi belum tentu dapat memberikan kemudahan dan kecepatan pengguna dalam menyelesaikan pekerjaannya.

H6 : Hipotesis bahwa Kegunaan yang dirasakan pada Sistem KRS On-line Universitas Amikom Yogyakarta memiliki pengaruh signifikan terhadap Kepuasaan Pengguna diterima karena nilai $\mathrm{p}=0.00$ lebih kecil dari $0.05(0.00<0.05)$. Hal ini menunjukkan bahwa kegunaan yang dirasakan menjadi faktor penting bagi kepuasaan pengguna. Hasil kuesioner menunjukkan, responden merasa lebih cepat dan lebih mudah dalam mengerjakan tugasnya. Misalnya, untuk mengisi KRS mahasiswa tidak harus datang ke kampus karena sistem ini memberikan manfaat akses fleksibel artinya, mahsiswa dapat mengisi KRS secara On-line baik menggunakan internet sendiri di rumah maupun dengan menggunakan hostpot di kampus.

\section{Kesimpulan}

1. Kualitas sistem dan kualitas informasi masuk dalam kategori sedang, ini menujukkan bahwa kedua variabel ini dinilai cukup baik atau cukup memuaskan pengguna sedangkan kegunaan yang dirasakan dan kepuasaan pengguna masuk dalam kategori tinggi, ini menunjukkan bahwa kedua variabel ini dinilai baik atau memuaskan bagi pengguna.

2. Dengan melibatkan variabel kualitas informasi dan kegunaan yang dirasakan sebagai mediating variabel maka dapat diketahui bahwa kualitas informasi dapat mempengaruhi kualitas sistem terhadap kegunaan yang dirasakan dengan pengaruh totalnya sebesar 0.703 dan kegunaan yang dirasakan dapat mempengaruhi kualitas informasi terhadap kepuasaan pengguna dengan memberikan pengaruh totalnya sebesar 0.383 . 


\section{Daftar Pustaka}

Aswar, S. (2006). Validasi dan Reabilitasi Instrumen, Pustaka Pelajar. Yogyakarta.

Santoso, Singgih., (2015) Amos 22 untuk Structural Equation Modelling, PT. Elex Media Komputindo, Jakarta.

Sitinjak, Tumpal, JR., Sugiarto. (2006). LISREL, Graha Ilmu, Yogyakarta.

Thomas Pramuji Singgih Riyanto. (2018). Analisis Kesuksesan Sistem Informasi KRS OnLine Universitas Amikom, Yogyakarta. Jurnal Teknologi Respati, Vol 13, No. 1. Yogyakarta

Yuliana, K. (2016). Model Kesuksesan Sistem Informasi Delone dan McLean untuk Evaluasi Sistem Informasi Pos pada PT. Pos Indonesia (Persero) Divisi Regional VI Semarang, Jurnal INFOKAM, No. II Th. XII, hlm. 13-23.

Davis, F. D. (1989). Perceived Usefulness, Perceived Ease of Use, and User Acceptance of Information Technology. MIS Quarterly, 13(3), 319-340.

Montesdioca, G. P. Z. dan Macada, A. C. G. (2015) Quality Dimensions of the DeloneMcLean Model to Measure User Satisfaction: an Empirical Test on the Information Security Context, Hawaii International Conference on System Sciences ke-48.

Palvia, P. C. (1996). A Model and Instrument For Measuring Small Business User Satisfaction With Information Technology. Information and Management, 31(3), 151163.

Wixom, B. H., \& Todd, P. A. (2005). A Theoretical Integration Of User Satisfaction And Technology Acceptance. Information Systems Research, 16(1), 85-102.

DeLone W. H., McLean, E. R. (1992) Information Systems Succes: The Quest for the Dependent Variabel, Information Systems Res Vol 3, pp 60-95 Mar.

Kassim, E. S., Jailani, S., Hairuddin, H., \& Zamzuri, N. H. (2012). Information System Acceptance and User Satisfaction: The Mediating Role of Trust, Procedia - Social and Behavioral Sciences, 57, 412-418. https://doi.org/10.1016/j.sbspro.2012.09.1205. Diakses 25 Maret 2018. 